\title{
PERILAKU IBU BALITA MEMBAWA ANAKNYA MENIMBANG KE POSYANDU DI WILAYAH KERJA PUSKESMAS KERANGGAN KOTA TANGERANG SELATAN TAHUN 2018
}

\author{
Lela Kania Rahsa Puji, Humaira Fadhilah, Monica Amanda \\ Sekolah Tinggi Ilmu Kesehatan Kharisma Persada \\ Tangerang Selatan, 15417 \\ E-mail : lila.kania@gmail.com
}

\begin{abstract}
ABSTRAK
Cakupan penimbangan balita dapat diukur dengan kunjungan secara rutin di Posyandu untuk menimbang balita. Penelitian ini menggunakan desain deskriptif analitik studi kolerasi dengan pendekatan cross sectional. Responden penelitian ini adalah 107 ibu balita di wilayah Kerja Puskesmas Keranggan Kota Tangerang Selatan Tahun 2018. Hasil analisa data dengan chi-square dengan nilai p sebesar 0,000 ( $<<0,005)$, menunjukkan bahwa terdapat hubungan antara pengetahuan, sikap, jarak ke Posyandu, Pembinaan dari Tenaga Kesehatan, dukungan keluarga, dukungan kader, dukungan tokoh masyarakat dengan Perilaku Ibu Balita Membawa Anaknya Menimbang ke Posyandu di wilayah Kerja Puskesmas Keranggan Kota Tangerang Selatan Tahun 2018. Berdasarkan hasil penelitian disimpulkan (1) 8,1\% pernyataan kuesioner terendah pada pengetahuan ibu balita dengan kategori perilaku kurang baik, (2) 33,8\% sikap ibu balita dengan kategori kurang baik, (3) 30,8\% jarak ke Posyandu dengan kategori jarak jauh, (4) 24,4\% pembinaan dari Tenaga Kesehatan pada ibu balita dengan kategori tidak aktif, (5) 53,8\% ibu balita yang tidak memiliki dukungan keluarga, (6) 30,0\% ibu balita yang tidak memiliki dukungan kader, (7) 12,8\% ibu balita yang tidak memiliki dukungan dari tokoh masyarakat. (8) Ada hubungan antara pengetahuan, dukungan kader dan dukungan tokoh masyarakat dengan nilai $P$ value $=(0,001), P$ value $=(0,050)$, dan $P$ value $=(0,001)$ terhadap perilaku ibu balita membawa anaknya menimbang ke Posyandu di wilayah kerja Puskesmas Keranggan Kota Tangerang Selatan Tahun 2018. Disarankan agar masyarakat terutama ibu balita mendapatkan informasi yang lebih detail tentang perilaku membawa balita untuk berkunjung ke Posyandu dari Tenaga Kesehatan, kader dan tokoh masyarakat sekitar.
\end{abstract}

Kata kunci : Perilaku, Ibu Balita, Posyandu

\begin{abstract}
The coverage of weighing can be measured by visits regularly to Posyandu for weigh toddler weight. This research use descriptive analytic design of correlation study with cross sectional approach. The respondents of this study were 107 respondents in the Work Area of Puskesmas Keranggan Tangerang Selatan 2018. The result of data analysis with chi-square with p value of $0.000(p<0,005)$ indicated that there was a correlation between knowledge, attitude, distance to Posyandu, Health Personnel, family support, cadre support, support of community leaders with Toddler Behavior Carrying its Children Considering to Posyandu in the Working Area of Puskesmas Keranggan Tangerang Selatan 2018. Based on the research result, it is concluded (1) $8.1 \%$ statement of the lowest questionnaire on the knowledge of the less behaviour. (2) $33.8 \%$ attitude on mother of toddler with bad attitude, (3) 30.8\% distance to Posyandu with long distance category, (4) 24,4\% coaching from health manpower on mother of toddler with inactive category (5) 53.8\% of mothers who did not have family support, (6) $30.0 \%$ of mothers who did not have kader posyandu support, (7) $12.8 \%$ of mothers who did not have support from community leaders. (8) There is correlation between knowledge, kader posyandu support and support of public figure with value of Pvalue = (0,001), Pvalue = (0,050), and Pvalue $=(0,001)$ to mother behavior of toddler bringing child weighing to Posyandu in work area of Puskesmas Keranggan Tangerang Selatan 2018. It is recommended that the community, especially mothers of toddlers, get more detailed information about the behavior of bringing toddlers to visit Posyandu from Health Workers, kader and local community leaders.
\end{abstract}

Keywords $\quad$ : behaviour, mother of toddler, Posyandu 


\section{PENDAHULUAN}

\begin{tabular}{lrrr}
\multicolumn{2}{c}{ Pembangunan } & kesehatan pada \\
hakekatnya adalah & upaya yang \\
dilaksanakan & oleh semua komponen
\end{tabular}
Bangsa Indonesia yang bertujuan untuk meningkatkan kesadaran, kemauan, dan kemampuan hidup sehat bagi setiap orang agar terwujud derajat kesehatan masyarakat yang setinggi-tingginya, sebagai investasi bagi pembangunan sumber daya manusia yang produktif secara sosial dan ekonomis (Indah, 2015).

Pos Pelayanan Terpadu (Posyandu) meliputi keterkaitan dengan beberapa program Puskesmas yaitu Program Gizi, Imunisasi, Kesehatan Ibu dan Anak, KB dan Promosi Kesehatan (Depkes, 2013). Pelaksanaan penimbangan pada balita dapat dilakukan di Pos Pelayanan Terpadu (Posyandu). Posyandu merupakan salah satu bentuk Upaya Kesehatan Berbasis Masyarakat (UKBM) yang dikelola dan diselenggarakan dari, oleh, untuk, bersama masyarakat dalam penyelenggaraan pembangunan kesehatan yang memiliki tujuan untuk mempercepat penurunan Angka Kematian Ibu (AKI), Angka Kematian Bayi (AKB) dan Angka Kematian Anak Balita (AKABA) (Kemenkes RI, 2013).

Cakupan penimbangan balita dapat diukur dengan frekuensi kunjungan balita untuk menimbang berat badan secara rutin enam bulan terakhir (Kemenkes RI, 2015).

Ibu merupakan bagian dari keluarga balita berperan sebagai seorang yang mengandung, melahirkan, menyusui, dan mengasuh memberikan pengaruh besar terhadap tumbuh kembang balita. Tingkat partisipasi masyarakat memeriksakan kesehatan balitanya ke Pos Pelayanan Terpadu (Posyandu) masih rendah. Kondisi ini salah satunya dipengaruhi oleh cara pandang orang tua yang merasa anaknya tidak perlu lagi dibawa ke Posyandu seiring dengan pertambahan umur, selain itu, minimnya kepercayaan para orang tua terhadap kinerja kader Posyandu juga berkorelasi positif terhadap jumlah kunjungan balita ke Posyandu. Padahal Posyandu merupakan ujung tombak layanan kesehatan dasar masyarakat. Penimbangan rutin dan penyuluhan kesehatan dari kader Posyandu juga penting disadari oleh para orang tua khususnya yang memiliki balita untuk memantau perkembangan kesehatan buah hatinya (Ramadini dkk, 2013).

Perilaku adalah suatu tindakan yang mempunyai frekuensi, lama dan tujuan khusus baik yang dilakukan secara sadar maupun tanpa sadar (Green, 1980). Perilaku kadarzi pada keluarga memiliki 
balita 6-59 bulan adalah salah satunya menimbang balita secara teratur (Kemenkes RI, 2007).

Salah satu indikator penentu keberhasilan tingginya tingkat kesehatan masyarakat adalah angka kematian bayi dan balita. Berdasarkan peringkat yang dikeluarkan Human Development Index (HDI) tahun 2009 yang dikeluarkan UNDP (United Nations Developments Program), Indonesia menempati urutan ke 111 maju seperti Australia tingkat kematian bayi dan balita adalah 6 per 1000 kelahiran, yang sama juga dimiliki oleh Malaysia. Di Indonesia, angka kematian bayi dan balita adalah 41 per 1000 kelahiran (Kemenkes RI, 2011).

AKABA di Indonesia mengalami penurunan yaitu antara tahun 2003 sampai 2012 dari 46/1.000 menjadi 40/1.000 kelahiran hidup (BPS, 2012). Millenium Development Goals (MDGs) menetapkan nilai normatif AKBA yaitu sangat tinggi dengan nilai > 140 per 1.000 kelahiran hidup, tinggi dengan nilai 71-140 per 1.000 kelahiran hidup, sedang dengan nilai 20-70 per 1.000 kelahiran hidup, dan rendah dengan nilai < 20 per 1.000 kelahiran hidup. Artinya untuk Indonesia sendiri masuk kedalam kategori sedang (BPS, 2012).

Tumbuh kembang seorang anak dapat dikontrol sejak dini, pemantauan pertumbuhan balita sangat penting dilakukan sejak awal untuk mengetahui adanya gangguan pertumbuhan (growth faltering) (Syafrudin $\mathrm{dkk}, \quad 2009)$. Pertumbuhan pada balita dapat dipantau melalui penimbangan berat badan anak setiap bulan. Pemantauan pertumbuhan balita yang dilakukan setiap bulan menunjukkan bahwa presentase balita umur 6-59 bulan yang tidak pernah ditimbang dalam enam bulan terakhir cenderung meningkat dari 25,5\% (2007), $23,8 \%$ (2010) menjadi $34,3 \% \quad$ (2013) (Kemenkes RI, 2013).

Balita yang ditimbang tidak teratur memiliki resiko 1,5 kali mengalami gagal tumbuh dibandingkan yang ditimbang teratur (Ramadini, 2013). Peran Serta Masyarakat (PSM) adalah salah satu bentuk dari Upaya Kesehatan Bersumber Daya Masyarakat (UKBM) yang merupakan sarana penyediaan data dan untuk melakukan evaluasi atas program yang telah dilaksanakan. Sumber daya ini dikelola oleh, dari, untuk dan bersama masyarakat, dengan bimbingan petugas Puskesmas, lintas sektoral dan lembaga. Kelurahan Keranggan memiliki Posyandu Purnama sebanyak 29 unit, Posyandu Mandiri sebanyak 3 unit, sedangkan Kelurahan Kademangan memiliki Posyandu Purnama sebanyak 79 unit, 
Posyandu Mandiri sebanyak 7 unit (Data

\section{METODE}

Penelitian ini menggunakan pendekatan kuantitatif dengan bentuk desain studi cross sectional, dimana variabel independen dan variabel dependen diamati pada waktu yang bersamaan (satu waktu) (Notoatmodjo, 2010). Populasi penelitian ini adalah seluruh ibu-ibu yang memiliki anak usia 659 bulan tinggal di wilayah kerja Puskesmas Keranggan Kota Tangerang Selatan tahun 2018.

\section{HASIL}

Penelitian dilakukan di wilayah kerja Puskesmas Keranggan Kota Tangerang Selatan dengan menggunakan teknik pengambilan sampling yaitu quota sampling. Berdasarkan permasalahan yang diambil, peneliti mendapatkan hasil analisis univariat dan analisis bivariat sebagai berikut.

\section{Analisis Univariat}

Pada analisis univariat ini akan mendapatkan distribusi frekuensi dari masing-masing variabel penelitian, yang meliputi variabel dependen perilaku ibu balita membawa anaknya menimbang ke Posyandu, variabel independen pada penelitian ini jarak ke
Puskesmas Keranggan, 2016).

Sampel dalam penelitian ini adalah ibu yang mempunyai anak usia 6-59 bulan tinggal di wilayah kerja Puskesmas Keranggan Kota Tangerang Selatan tahun 2018. Pemilihan sampel hanya ibu yang memiliki balita 6-59 bulan dikarenakan pengukuran cakupan penimbangan balita dilihat dari jumlah penimbangan 6 bulan terakhir (Kemenkes RI, 2015).

$$
\begin{aligned}
& \text { Posyandu, pembinaan dari tenaga } \\
& \text { kesehatan, dukungan keluarga, } \\
& \text { dukungan kader dan dukungan tokoh } \\
& \text { masyarakat dan variabel confounding } \\
& \text { yaitu pengetahuan dan sikap. }
\end{aligned}
$$

\section{a. Pengetahuan}

Dari penelitian yang dilakukan di wilayah kerja Puskesmas Keranggan Kota Tangerang Selatan, distribusi pengetahuan ibu balita membawa anaknya menimbang ke Posyandu dapat dilihat pada tabel sebagai berikut: 
Tabel 1. Distribusi Pengetahuan Ibu Balita

\begin{tabular}{lcc}
\hline Pengetahuan Ibu Balita & Jumlah & Persentase (\%) \\
\hline Kurang & 37 & 34,6 \\
Cukup & 35 & 32,7 \\
Baik & 35 & 32,7 \\
Total & $\mathbf{1 0 7}$ & $\mathbf{1 0 0}$ \\
\hline
\end{tabular}

Berdasarkan Tabel 1, distribusi pengetahuan ibu balita didapatkan persentase tertinggi sebesar $34,6 \%$

b. Dukungan Keluarga

Dari penelitian yang dilakukan di wilayah kerja Puskesmas Keranggan Kota Tangerang Selatan, dengan kategori pengetahuan kurang dari total sampel yaitu $107 \mathrm{ibu}$ balita.

distribusi dukungan keluarga ibu balita membawa anaknya menimbang ke Posyandu dapat dilihat pada tabel sebagai berikut:

\section{Tabel 2. Distribusi Dukungan Keluarga}

\begin{tabular}{lcc}
\hline Dukungan Keluarga & Jumlah & Persentase (\%) \\
\hline Tidak Ada & 13 & 12,1 \\
Ada & 94 & 87,9 \\
Total & $\mathbf{1 0 7}$ & $\mathbf{1 0 0}$ \\
\hline
\end{tabular}

Berdasarkan Tabel 2, distribusi dukungan keluarga didapatkan persentase tertinggi sebesar 87,9\% dengan kategori ada, sedangkan

\section{Analisis Bivariat}

Analisis bivariat merupakan analisis untuk mengetahui hubungan antara variabel independen, variabel persentase terendah sebesar $12,1 \%$ dengan kategori tidak ada dari total sampel yaitu 107 ibu balita.

confounding dengan variabel dependen yang menggunakan metode analisis melalui uji chi-square (Notoatmodjo, 2010). 
a. Hubungan antara Pengetahuan dengan Perilaku Ibu Balita Membawa Anaknya menimbang ke Posyandu

Tabel 3 Hubungan antara Pengetahuan dengan Perilaku Ibu balita Membawa Anaknya Menimbang Ke Posyandu

\begin{tabular}{ccccccccc}
\hline & \multicolumn{9}{c}{$\begin{array}{c}\text { Perilaku Ibu Balita Membawa Anaknya } \\
\text { Penimbang ke Posyandu }\end{array}$} & Total & \% & $\begin{array}{c}\boldsymbol{P} \\
\text { value }\end{array}$ \\
\cline { 2 - 5 } & $\begin{array}{c}\text { Kurang } \\
\text { Baik }\end{array}$ & $\boldsymbol{\%}$ & Baik & $\boldsymbol{\%}$ & & & \\
\hline Kurang & 3 & 8,1 & 34 & 91,9 & 37 & 100 & \\
Cukup & 11 & 31,4 & 24 & 68,6 & 35 & 100 & 0,001 \\
Baik & 17 & 48,6 & 18 & 51,4 & 35 & 100 & \\
\hline
\end{tabular}

Berdasarkan tabel 3, didapatkan bahawa responden dengan pengetahuan kurang terhadap perilaku ibu balita sebanyak 3 responden $(8,1 \%)$ memiliki pengetahuan kurang baik dan tidak membawa anaknya dalam menimbang ke Posyandu dan 17 responden $(48,6 \%)$ dengan pengetahuan baik. Hasil uji chi- square didapatkan hasil dengan nilai $\mathrm{p} \quad$ sebesar $\quad 0,001 \quad(\mathrm{p}<0,05)$ menunjukkan bahwa hipotesis yang menyatakan ada hubungan antara pengetahuan dengan perilaku ibu balita membawa anaknya menimbang ke Posyandu di wilayah kerja Puskesmas Keranggan Kota Tangerang Selatan Tahun 2018.

b. Dukungan keluarga dengan Perilaku Ibu Balita Membawa Anaknya menimbang ke Posyandu

Tabel 4. Hubungan antara Dukungan Keluarga dengan Perilaku Ibu Balita Membawa Anaknya Menimbang Ke Posyandu

\begin{tabular}{|c|c|c|c|c|c|c|c|}
\hline \multirow[b]{2}{*}{$\begin{array}{c}\text { Dukungan } \\
\text { Keluarga }\end{array}$} & \multicolumn{4}{|c|}{ Perilaku Ibu Balita } & \multirow[b]{2}{*}{ Jumlah } & \multirow[b]{2}{*}{$\%$} & \multirow[b]{2}{*}{$\begin{array}{c}P \\
\text { value }\end{array}$} \\
\hline & $\begin{array}{l}\text { Kurang } \\
\text { Baik }\end{array}$ & $\%$ & Baik & $\%$ & & & \\
\hline Tidak Ada & 7 & 53,8 & 6 & 46,2 & 13 & 100 & \\
\hline Ada & 24 & 25,5 & 70 & 74,2 & 94 & 100 & 0,050 \\
\hline Total & 31 & 29,0 & 76 & 71,0 & 107 & 100 & \\
\hline
\end{tabular}

Berdasarkan tabel 4, diketahui responden yang tidak ada dukungan keluarga dan perilaku kurang baik 7 $(53,8 \%)$, sedangkan responden yang ada dukungan keluarga 24 dari 94 orang $(25,5 \%)$ yang memiliki perilaku kurang baik. Hasil uji chi-square didapatkan hasil dengan nilai $\mathrm{p}$ sebesar 0,050 $(\mathrm{p}<0,05)$ menunjukkan bahwa hipotesis yang menyatakan ada hubungan antara dukungan keluarga dengan perilaku ibu balita membawa 
anaknya menimbang ke Posyandu di wilayah kerja Puskesmas Keranggan
Kota Tangerang Selatan Tahun 2018.

\section{DISKUSI}

\section{Pengetahuan}

Pengetahuan adalah kesan didalam fikiran manusia sebagai hasil penggunaan panca inderanya. Perilaku yang didasari oleh pengetahuan akan lebih langgeng dari pada perilaku yang tidak didasari oleh pengetahuan, sebab perilaku ini terjadi akibat adanya paksaan atau aturan yang mengahruskan untuk berbuat (Iqbal, 2007).

Pada penelitian ini didapatkan hasil ibu balita yang memiliki pengetahuan kurang $8,1 \%$, ibu balita yang memiliki pengetahuan cukup $31,4 \%$, dan ibu yang memiliki pengetahuan baik 48,6\%. Hasil tersebut lebih banyak responden yang memiiki pengetahuan baik. Berdasarkan penelitian sebelumnya yang dilakukan di Kota Lampung terdapat 63,9\% ibu meiliki pengetahuan baik terhadap penimbangan dan $36,1 \%$ ibu memiliki pengetahuan yang buruk (Reihan dkk, 2014).

Berdasarkan penelitian yang telah dilakukan di wilayah Kerja Puskesmas Keranggan Kota Tangerang Selatan Tahun 2018, hasil penelitian menggunakan uji chi-square didapatkan hasil 0,001 p-<0,05 dapat disimpulkan bahwa HO ditolak, artinya ada hubungan yang bermakna antara pengetahuan dengan perilaku ibu balita yang membawa anaknya dalam menimbang ke Posyandu.

Hasil penelitian ini juga sejalan dengan penelitian yang sudah dilakukan oleh Achmad Djamil 2016 menunjukkan nilai $p$ value 0,027 yang berarti bahwa ada hubungan yang signifikan antara pengetahuan ibu dangan perilaku ibu balita yang menimbang anaknya ke Posyandu di wilayah Kerja UPT Puskesmas Way Panji Kabupaten Lampung Selatan. Penelitian lain yang dilakukan oleh La Ode tahun 2013 yaitu terdapat hubungan antara pengetahuan ibu dengan kunjungan ibu balita ke Posyandu.

\section{Dukungan Keluarga}

Menurut teori Green, 1980 faktor penguat untuk seseorang berperilaku sehat yaitu berdasarkan dukungan keluarga. Ibu akan aktif ke Posyandu jika ada dorongan dari orang terdekat termasuk keluarga. Dukungan keluarga 
sangat berperan dalam memelihara dan mempertahankan status gizi balita yang optimal.

Hasil analisis diketahui bawa responden yang tidak ada dukungan dari keluarga untuk menimbang ke Posyandu 53,8\% dan ada dukungan dari keluarga 25,5\%. Dari hasil uji statistik chi-square diperoleh nilai $p$ value 0,050 yang dapat disimpulkan bahwa HO ditolak, artinya ada hubungan yang bermakna antara dukungan keluarga dengan perilaku ibu balita yang membawa anaknya dalam menimbang ke Posyandu di wilayah kerja Puskesmas Keranggan Kota Tangerang Selatan Tahun 2018.

\section{SIMPULAN}

Berdasarkan hasil penelitian faktorfaktor yang berhubungan dengan Perilaku Ibu Balita Membawa Anaknya Menimbang ke Posyandu di wilayah Kerja Puskesmas Keranggan Kota Tangerang Selatan Tahun 2018 maka dapat diambil kesimpulan bahwa ada

\section{DAFTAR PUSTAKA}

Adicondro, N., \& Purnamasari, A. (2011). Efikasi Diri, Dukungan Sosial Keluarga dan Self Regulated Learning. Jurnal Humanitas.

Achmad, Djamil. 2016. Faktor-faktor yang berhubungan dengan perilaku
Hasil penelitian ini sejalan dengan penelitian yang dilakukan oleh Reihan dkk tahun 2014 yaitu terdapat hubungan antara dukungan keluarga dengan partisipasi ibu menimbang anaknya ke Posyandu. Dalam penelitian ini juga sejalan dengan Achmad Djamil tahun 2016 menunjukkan bahwa nilai $p$ value $=0,010$ yang beraarti ada hubungan yang signifikan antara dukungan keluarga dengan perilaku ibu balita dalam menimbang anaknya ke Posyandu di wilayah kerja UPT Puskesmas Way Panji Kabupaten Lampung selatan.

hubungan yang bermakna antara pengetahuan ( $p$ value 0,001) dan dukungan keluarga ( $p$ value 0,050) dengan perilaku ibu balita yang membawa anaknya dalam menimbang ke Posyandu, di wilayah kerja Puskesmas Keranggan Kota Tangerang Selatan Tahun 2018.

ibu balita dalam menimbang anaknya ke Posyandu di wilayah kerja UPT Puskesmas Way Panji Kabupaten Lampung Selatan. Skripsi. Program Studi Kesehatan 
Masyarakat. STIKES Mitra Lampung.

Biro Pusat Statistik. 2012. Survey Demografi dan Kesehatan Indonesia (SDKI) 2012. BPS-BKKBN Depkes RI.

Green, Lawrence W 'dkk'. 1980. Health Education Planing A Diagnosic Approach. California: Mayfield publishing company.

Indah, Jamiatun Hasanah. 2015. Faktorfaktor yang berhubungan dengan perilaku ibu balita yang menimbang anaknya ke Posyandu di Wilayah Kerja Puskesmas Kelurahan Rorotan Kecamatan Cilingcing Jakarta Utara. Skripsi. UIN Jakarta.

Iqbal, Wahid Mubarak dkk. 2007. Promosi Kesehatan sebuah Pengantar proses belajar mengajar pendidikan. Yogyakarta: Graha Ilmu.

Kemenkes RI. 2007. Keputusan Menteri Kesehatan Republik Indonesia nomor: $\quad 747 / M e n k e s / S K / V I / 2007$ tentang Pedoman Operasional Keluarga Sadar Gizi di Desa Siaga. Jakarta: Kementrian Kesehatan RI.

Kementrian Kesehatan RI. 2011. Pedoman Umum Pengelolaan Posyandu. Jakarta: Kemenkes RI.

Kementrian Kesehatan RI. 2011. Profil Kesehatan Indonesia Tahun 2010. Jakarta: Kemenkes RI.

Kemenkes RI. 2013. Buku panduan kader Posyandu menuju keluarga sadar gizi. Jakarta: Kementrian Kesehatan RI.
Kemenkes RI. 2013. Buku 2 pedoman paket gizi masyarakat. Jakarta: Kementrian Kesehatan RI Direktorat Bina Gizi dan KIA.

Kemenkes RI. 2015. Pedoman teknis pemantauan status gizi. Jakarta: Kementrian Kesehatan RI Direktorat Bina Gizi dan KIA.

Kemenkes RI. 2015. Rencana aksi pembinaan gizi masyarakat. Jakarta: Kementrian Kesehatan RI Direktorat Bina Gizi dan KIA.

La Ode, Muhammad Syahir. 2013. Faktor-faktor yang berhubungan dengan kunjungan ibu yang mempunyai balita ke Posyandu wilayah kerja Puskesmas Tamalanrea Makasar. STIKES Nani Hasanuddin Makassar.

Notoatmodjo, Soekidjo. 2010. Metodologi Penelitian Kesehatan. Jakarta: Rineka Cipta.

Ramadini, dkk. 2013. Status gizi balita berdasarkan composite index of anthropometric failure. Jurnal Kesehatan Masyarakat Nasional vol. 7 no. 12

Reihan, Budi, Artha Susila Duarsa. 2014. Faktor-faktor yang berhubungan dengan partisipasi ibu untuk menimbang balita ke Posyandu. Jurnal Kedokteran Yarsi.

Syafrudin, Fatidhina, Yudhia. 2009. Promosi Kesehatan untuk mahasiswa kebidanan. Jakarta Timur: CV Trans Info Medika. 